\title{
Marine litter, future prospects for research
}

\author{
François Galgani * \\ Institut Français de Recherche pour l'Exploitation de la Mer, LER Provence Azur Corse, Bastia, France
}

Keywords: marine litter, microplastics, marine debris, trophic chains, chemicals, rafting

As far back as 1870, i.e., about 150 years ago, Jules Verne described the accumulation of debris in the convergence zone of the North Atlantic Ocean in his famous novel entitled "Twenty Thousand Leagues under the Sea." Many scientific reports have addressed this topic since and our main concern today is the ever increasing volume of marine litter invading the oceans in various and complex ways. One of the current main challenges is assessing the final destination of this litter. To date, its adverse effects on marine life have only occasionally been investigated and many questions remain unanswered. In addition to efforts to monitor and reduce litter, recent literature has underlined the scientific community's focus on specific issues such as (i) the evaluation of sources and inputs, (ii) transport and distribution at sea, (iii) the transport of litter and, in particular, plastics within the food web, and (iv) the types of chemicals and organisms likely to sorb or settle on debris and how they can be rafted over long distances. It is important to address these questions in a more detailed manner.

\section{EXTENT OF MARINE LITTER POLLUTION}

OPEN ACCESS

Edited by:

Hans Uwe Dahms,

Kaohsiung Medical University, Taiwan

Reviewed by:

Riaan Van Der Merwe, King Abdullah University of Science and Technology, Saudi Arabia

*Correspondence:

François Galgani

francois.galgani@ifremer.fr

Specialty section:

This article was submitted to Marine Pollution,

a section of the journal Frontiers in Marine Science

Received: 01 September 2015 Accepted: 09 October 2015 Published: 26 October 2015

Citation:

Galgani F (2015) Marine litter, future prospects for research.

Front. Mar. Sci. 2:87.

doi: 10.3389/fmars.2015.00087
A recent study evaluated globally the amount of litter entering the oceans every year at between 4.8 and 12.7 million tons for plastics alone (Jambeck et al., 2015). Little information exists however on the global freshwater input, with high quantities reported, up to 106 particles $/ \mathrm{m} 3$ in developed countries (Dris et al., 2015a). Atmospheric inputs, also, cannot be ignored. Suggested first to explain the high densities of particles found in a remote mountain lake in Mongolia distant from urban sources (Free et al., 2014), atmospheric fallout was estimated for the first time to better understand fluxes of microplastics to the watershed of the Seine river in Paris (Dris et al., 2015b). Microplastics fallout ranged from 29 to 280 particles $\mathrm{m}-2$ day-2 (average 118 , fibers accounting for $90 \%$ of the total particles) depending on the period when rainfall occurred. This will support new research, enabling a better understanding of fluxes to the oceans. Various recent studies (Eriksen et al., 2014) have revealed that the well-recognized oceanic gyres, improperly defined as "plastic continents," are less affected than coastal areas such as the Bay of Bengal and Mediterranean coast. Modelers will then need to focus on coastal areas, where transport mechanisms appear to be more complex; this could help explain observed patterns of debris travel and stranding. Locating deep-sea accumulation areas is another challenge. Recent assessments of floating large debris and microparticles (Eriksen et al., 2014; Cózar et al., 2015) have shown that quantities located on the surface are limited and that the presence of sinks should be considered.

The deep-sea floor is probably a final global sink for marine litter. However, long-term data is scarce and does not show any clear or significant trends with regards to variations in debris quantities (Law et al., 2010 for microplastics and Figure 1).

Recent litter evaluations in open oceans, resulting from 248 dives/trawls at deep sea sites (seamounts, banks, mounds, and ridges) in the Atlantic Ocean around Europe, together with concentration measurements above the Arctic Circle, indicate respective densities of 180 and 36.5 


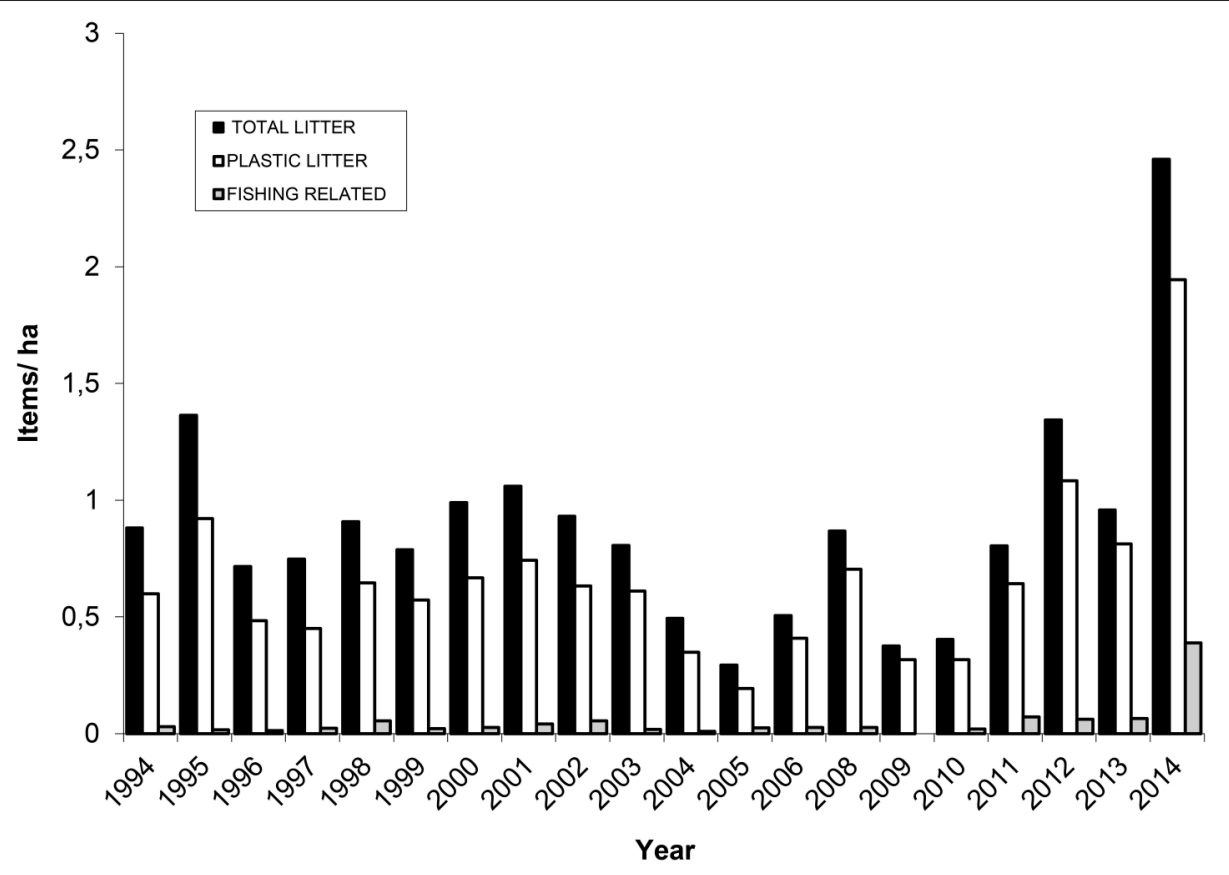

FIGURE 1 | Density of litter collected on the sea floor between 1994 and 2014 in the Gulf of Lion, Mediterranean Sea. Litter (mean values for 70 sites) was collected during the Mediterranean International Bottom Trawl Surveys (MEDITS) dedicated to fish stock assessments, using a stratified sampling scheme (protocol at http://www.sibm.it/SITO\%20MEDITS/principaleprogramme.htm) and $20 \mathrm{~mm}$ mesh. Results are expressed in items/ha.

plastic debris items per square $\mathrm{km}$ (Pham et al., 2014). Other studies in the Indian Ocean and Atlantic Ocean indicate densities of 555 and 483 debris items per square $\mathrm{km}$ (Woodall et al., 2015). The volume of litter in the three main oceans, which cover a deepsea surface area of $300,875,000$ square $\mathrm{km}$ (worldatlas.com), may range roughly from 10,982,000.00 (\#11 billion) to 54,157,500,000 (\#54 billion) items, excluding the Arctic and Antarctic Ocean, where litter is less frequent (Barnes et al., 2009).

Regarding coastal waters, 6631 samples collected during 14 surveys from relevant areas (California, Japan, Hawaii, China, Korea, Florida, the North Sea, Azores, Portugal, the Gulf of Mexico, Brazil, and Red Sea) indicate a mean and balanced concentration of 723 plastic items/square $\mathrm{km}$. As the average margin area is $84,245,000 \mathrm{~km}^{2}$ (worlsatlas.com), this represents $60,909,135,000$ items (\#61 billion). Taking into account the additional 525,615,958 (\#0.5 billion) plastic items over an area of $2,936,000 \mathrm{~km}^{2}$ in the Mediterranean and Black Sea found (295 samples collected during seven surveys), we obtain a very rough estimated global range of 71.5-116 billion large plastic debris items on the sea floor, without consideration to microplastics that are largely distributed in deep sea sediments (Van Cauwenberghe et al., 2013; Woodall et al., 2014). More accurate estimates, also taking into account weight, is the next challenge. Moreover, the location of deep sea floor debris needs to be more precisely pinpointed; although debris is present on all ocean floors, we do not possess any inventories of significant debris accumulation in deep and remote areas. We know very little about deep sea currents and probable deep convergence zones. Additional "patches of plastic" and "deep sea gyres" remain to be discovered.
The fragmentation of floating plastics is related to weathering. The physical disintegration of the weakened material is due to winds and waves, or fouling. The degradation rates of polymer-type chemical additives and environmental factors (UV radiation, temperature, oxygen, ph) may vary considerably depending on the marine habitat (i.e., beaches, surface water, deep-sea, or sediment). Furthermore, biofilms are developing on plastics at sea, which play a vital role in degradation (Dussud and Ghiglione, 2014). We know nothing about the kinetics of polymer degradation in dark, deep-water environments, where water temperature and oxygen content are far lower. Although low-density particles tend to float on the sea surface, biofouling can increase the density of plastics, causing them to sink (Morét-Ferguson et al., 2010; Zettler et al., 2013); this partly explains the low estimates to date on open-ocean surfaces (Eriksen et al., 2014). However, the situation is probably more complex, since after sinking, biofilms, and fouled organisms may not survive or be grazed, disappearing and enabling vertical movements of particles back to the surface. Alternatively, aggregate microparticles in organic matter (i.e., marine snow) may be a route to deep sea sediment (Van Cauwenberghe et al., 2013), although the presence of microplastics in aggregates remains to be demonstrated.

Although scientists have focused on microplastics in recent years, the study of smaller debris has proved difficult due to limited methods. The next step will consist of designing and developing detection methods enabling the quantification of nanoparticles. Microplastics represent just $10 \%$ of the total weight of floating plastic particles (Eriksen et al., 2014). This 
percentage may be lower for nanoparticles. Then, in view of the specific impact potentially caused by chemical release, larger debris are more important and should be a priority study topic. On the contrary, in view of the dispersion of rafted debris, the vast quantities of small particles ( 5 trillion microplastics, Eriksen et al., 2014) and nanoparticles must equally be given priority status, as quantities may be even higher than currently thought.

\section{POSSIBLE IMPACTS OF MARINE LITTER}

Entanglement, which is often caused by ghost fishing gear, is one of the most damaging effects of debris, although to a lesser extent than microplastics, and can represent up to $0.5 \%$ of captures, depending on species and locations. Furthermore, in view of the economic value of nets, which can be repaired and recycled (Macfayden et al., 2009), the rationalization of fishing practices through retrieving debris in large fishing areas helps prevent the loss of nets and assists their recovery.

\section{Transfer through Trophic Levels?}

Numerous surveys have reported the introduction of plastics and other types of debris into the marine food web through ingestion by marine organisms, ranging from zooplankton to major predators. Regarding microplastics, 45 fish and invertebrate species, including deep sea species, and 56 bird species, have been found to ingest microplastics (GESAMP, 2015). Although this phenomenon may be widespread, there appears to be a low incidence and disparities between species, approaches, authors, and sites depending on the reports (Van Cauwenberghe et al., 2015). Current methodological achievements include the harmonization of sorting and quantification techniques for stomach content, together with newly-derived indexes. Scientists are also currently focusing on the risk of plastic transfer via food chains. The digestion time for ingested particles ranges from several hours in the case of planktonic species (Cole et al., 2013) to 2 weeks on average in the case of seaturtles (Camedda et al., 2014) and retention efficiency rate is $0.003 \%$ in mussels only, (Van Cauwenberghe et al., 2015) thus strongly reducing the risk of transfer to predators. A survey conducted on mussels several years ago described the translocation of microparticles in tissues and phagocytosis in cultivated cells (Browne et al., 2008; von Moos et al., 2012). However, this topic remains open to discussion, as it is difficult to understand how a process such as digestion, the purpose of which is to degrade tissues into molecules, oligomers, and polymers to ease transfer, can allow the translocation of larger particles (more than $10 \mu \mathrm{m}$ ) through intestinal brush borders or gill cells, when the internal body is protected from other types of particles like sand or pelites, that are excreted from microplastics (Devriese et al., 2015). Nevertheless, ingested debris clearly interfere with the digestion process and physiology. This issue is particularly serious in terms of public health, in that many impacted species are sold for consumption. Indeed, filterfeeding shellfish have been shown to ingest substantial quantities of microparticles (Van Cauwenberghe and Janssen, 2014; Van Cauwenberghe et al., 2015). However, some species appear to represent a lesser risk, as people generally avoid eating fish digestive glands.

Persistent organic pollutants (POPs) may be transferred or bioaccumulated due to the high capacity of many plastics to sorb lipophilic compounds (Rochman et al., 2013). Some chemicals have a low solubility capacity in sea water and tend to migrate into water microlayers where they may be biomagnified. PCBs, DDEs, and phenanthrene sorb onto debris, with partition coefficients ranging from 13,000 to 1,000,000 in sea water (Engler, 2012). Most of these endocrine-disrupting chemicals have a potentially harmful effect on organisms, thus affecting population viability (Teuten et al., 2009). However, the definition of the total level of contaminants available to organisms still remains an issue, the highest amounts of litter absorbed contaminants being far lower than the amounts of chemicals dissolved, accumulated in sediments or ingested through feeding. On beaches for example, direct contact with microplastics remains scarce, as they may only constitute a small proportion of particles, whereas sand adsorb chemicals in a larger extent (Galgani et al., 2011). In some cases (Koelmans et al., 2013) bioaccumulation may be reduced due to a "dilution" of contaminants and "cleaning" mechanisms through microplastic ingestion.

Plastic additives (PAs), which are added in various quantities to polymers, may leach out of the matrix with time and have toxic and endocrine disruptive effects on marine organisms when ingested (Oehlmann et al., 2009). To date, concentrations of these components at sea remain very low (Flint et al., 2012) and may not be relevant in terms of chronic contamination and effects.

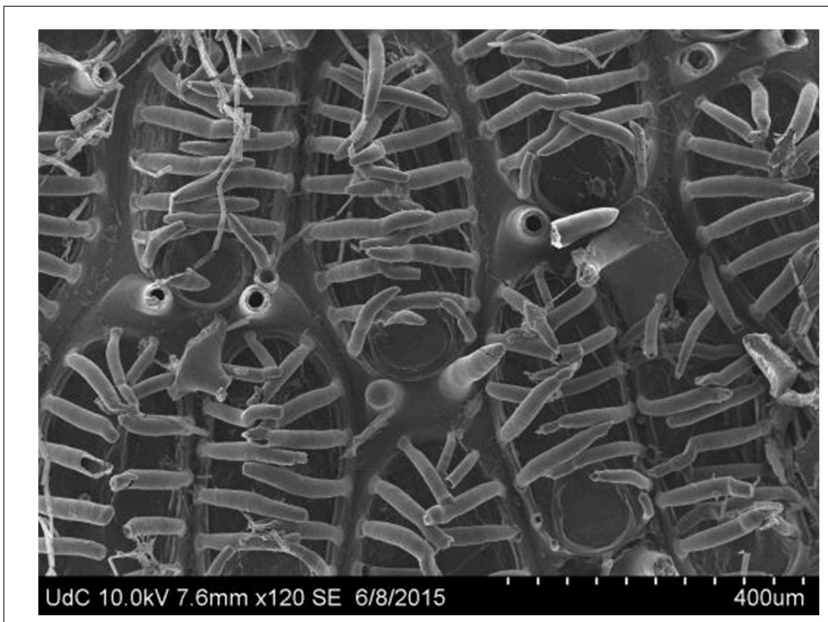

FIGURE 2 | Bryozoa (Electra angulata Levinsen, 1909) fixed on a Mediterranean floating plastic collected in the Northern Tyrrhenian Sea $\left(47^{\circ} 32,02 \mathrm{~N} / 09^{\circ} 32,16 \mathrm{E}\right)$. Pelagic plastic items are commonly colonized by a diversity of encrusting and fouling epibionts. Most of these are sessile, hard-shelled or crustose organisms, with predominant bryozoans (Gregory, 2009). Plastic samples were rinsed in salted, distilled water (38 psu), fixed in ethanol containing a grading concentration of HMDS (HexaMethylDiSilazane), then glued and metallised on a filter using gold-Palladium prior to observation using a Side Scan electronic microscope (Hitachi S-3400N) under secondary vacuum and $10 \mathrm{kV}$ acceleration as described by Antonelli et al., 2010 (credit M. Garrido and Y. Quilichini, University of Corsica, 2015). 


\section{Litter Transport}

The hydrophobic surface of plastic marine debris stimulates microbial colonization, producing what is referred to as "microbial reefs," where they may contribute to the selfbreakdown or degradation of plastics (Dussud and Ghiglione, 2014).

The large amounts of debris released into the ocean have greatly increased quantities of rafting material, hence increasing opportunities for the dispersion of many and various marine organisms (Deudero and Alomar, 2015). Although microorganisms and fish pathogens may fix on various surface areas including plastics (Harrison et al., 2011; Pham et al., 2012), toxic dinoflagellates were shown to be transported on plastics as far back as 2003 (Maso et al., 2003) and particle dispersion may favor the dispersion of these species, which may be toxic to humans. More recently, microorganisms from the Vibrio family were also shown to be capable of rafting through plastics and microplastics (Zettler et al., 2013). The next step will consist of listing species associated with litter and assessing the impact of these various mechanisms on the dispersion of toxicity and pathogenicity.

Finally, ocean litter may impact populations and support the colonization of new habitats. Good examples of these include insects such as Halobates micans, which use plastic pellets as oviposition sites (Goldstein et al., 2012), or the benthic foraminifer Rosalina concinna, which colonize floating plastics in the planktonic (Tretomphalus) stage and reproduce when surface waters are at temperatures above $18^{\circ} \mathrm{C}$ (Jorissen, 2014). Understanding the wide-scale transport of debris and associated species and to what extent it influences species assembly, endemic species and ecosystems (Figure 2), will provide us with a better understanding of connectivity between remote areas.

\section{RECOMMENDATIONS}

Due to the lack of standardized protocols for debris detection, sampling and extraction, the comparability of available data must be improved with respect to different sizes, classes, and categories (including nanoplastics), sampling procedures, analytical methods and reference materials. Surveys may require the development or refining of regional and coastal models, characterized by higher spatial and temporal resolutions, in order to better evaluate the budgets required for marine litter campaigns and locate "hot spots." In order to support future reduction measures and strategies, we need to improve our

\section{REFERENCES}

Antonelli, L., Quilichini, Y., and Marchand, B. (2010). Biological study of Furnestinia echeneis Euzet and Audouin 1959 (Monogenea:Monopisthocotylea: Diplectanidae), parasite of cultured Gilthead sea bream Sparus aurata (Linnaeus 1758) (Pisces: Teleostei) from Corsica. Aquaculture 307, 179-186. doi: 10.1016/j.aquaculture.2010.07.028

Barnes, D. K., Galgani, F., Thompson, R. C., and Barlaz, M. (2009). Accumulation and fragmentation of plastic debris in global environments. Philos. Trans. $R$. Soc. B 364, 1985-1998. doi: 10.1098/rstb.2008.0205

Browne, M. A., Dissanayake, A., Galloway, T. S., Lowe, D. M., and Thompson, R. C. (2008). Ingested microscopic plastic translocates to the circulatory knowledge of the persistence of plastics at sea, be capable of describing degradation and biodegradation processes in full, assess the relative importance of microorganisms and develop markers/indicators to measure plastic lifespan at sea.

Investigating the impact of marine litter on all trophic levels of marine biota on a similar temporal and spatial scale is a matter of increasing urgency. With regards to biodiversity, it is essential to focus research on ingestion, bioaccumulation and possible transfer through the food web and to deeper waters. In order to study the effects of marine litter on marine populations, we must also develop methods to estimate mortality rates and effects on population dynamics.

The next step should logically consist of identifying highlyvulnerable species in terms of toxic, chemical, and biological effects. This will support targeted investigations and the ranking of factors (chemicals, litter types, toxic species, etc.). We will also need to fully comprehend ecological impacts on marine organisms. Understanding the ecology of microbial and marine life in environments affected by litter using the so called "-omics" will also help us understand (i) the role of litter in alien invasions and/or invasive species through unsuitable habitats, and (ii) potential risks of pathogenicity.

Finally, most countries and managers are currently implementing comprehensive measures and reforms relating to marine litter, ranging from waste prevention to environmentallyfriendly waste disposal. Various, mainly preventive measures, such as recycling, banning plastics bags, improving port reception facilities and incentives/disincentives relating to littering, together with curative actions such as beach cleaning, fishing for litter and cleaning inland pathways, have recently been experimented and implemented. Nonetheless, assessing the cost of plastic litter in the marine environment in economic, environmental, and human health terms remains a challenge to be addressed before considering additional solutions. We may need to rely on new concepts, such as the discovery of eco-friendly materials. This is food for a new debate.

The author is also of the opinion that the full extent of economic, environmental, and health impacts need to be assessed before viable solutions can be considered.

\section{FUNDING}

This work was funded through the Institutional support of IFREMER and by the French ministry of Environment (MEDDE) under the convention 15/1211821/NYF. system of the mussel Mytilus edulis. Environ. Sci. Technol. 42, 5026-5031. doi: $10.1021 /$ es 800249 a

Camedda, A., Marra, S., Matiddi, M., Massaro, G., Coppa, S., Perilli, A., et al. (2014). Interaction between loggerhead sea turtles (Caretta caretta) and marine litter in Sardinia (Western Mediterranean Sea). Mar. Environ. Res. 100, 25-32. doi: 10.1016/j.marenvres.2013.12.004

Cole, M., Lindeque, P., Fileman, E., Halsband, C., Goodhead, R., and Moger, J. (2013). Microplastic ingestion by zooplankton. Environ. Sci. Technol. 47, 6646-6655. doi: 10.1021/es400663f

Cózar, A., Sanz-Martín, M., Martí, E., González-Gordillo, J., Ubeda, B., Gálvez, J., et al. (2015). Plastic accumulation in the Mediterranean Sea. PLoS ONE 10:e0121762. doi: 10.1371/journal.pone.0121762 
Deudero, S., and Alomar, C. (2015). Mediterranean marine biodiversity under threat: reviewing influence of marine litter on species. Mar. Pollut. Bull. 98, 58-68. doi: 10.1016/j.marpolbul.2015.07.012

Devriese, L., van der Meulen, M., Maes, T., Bekaert, K., Paul-Pont, I., Frère, L., et al. (2015). Microplastic contamination in brown shrimp (Crangon crangon, Linnaeus 1758) from coastal waters of the Southern North Sea and Channel area. Mar. Pollut. Bull. 98, 179-187. doi: 10.1016/j.marpolbul.2015.06.051

Dris, R., Gasperi, J., Rocher, V., Saad, M., Renault, N., Tassin, B. (2015b). Microplastic contamination in an urban area: a case study in Greater Paris. Environ. Chem. 12, 592-599. doi: 10.1071/EN14167

Dris, R., Imhof, H., Sanchez, W., Gasperi, J., Galgani, F., Tassin, B., et al. (2015a). Beyond the ocean: contamination of freshwater ecosystems with (micro-)plastic particles. Environ. Chem. 12, 539-550. doi: 10.1071/EN14172

Dussud, C., and Ghiglione, J. F. (2014). "Bacterial degradation of synthetic plastics. CIESM Monograph $n^{\circ} 46$ on Marine Litters pp 43-48," in Marine litter in the Mediterranean and Black Seas, F. Briand, (Monaco: CIESM Publisher) 180.

Engler, R. E. (2012). The complex interaction between marine debris and toxic chemicals in the ocean. Environ. Sci. Technol. 46, 12302-12315. doi: 10.1021/es3027105

Eriksen, M., Lebreton, L. C., Carson, H. S., Thiel, M., Moore, C. J., Borerro, J. C., et al. (2014). Marine plastic pollution in the world's oceans. PLoS ONE 9:e111913. doi: 10.1371/journal.pone.0111913

Flint, S., Markle, T., Thompson, S., and Wallace, E. (2012). Bisphenol A exposure, effects, and policy: a wildlife perspective, a review. J. Environ. Manage. 104, 19-34. doi: 10.1016/j.jenvman.2012.03.021

Free, C. M., Jensen, O. P., Mason, S. A., Eriksen, M., Williamson, N. J., and Boldgiv, B. (2014). High-levels of microplastic pollution in a large, remote, mountain lake. Mar. Pollut. Bull. 85, 156-163. doi: 10.1016/j.marpolbul.2014. 06.001

Galgani, F., Ellebrake, K., Fries, E., and Goreux, C. (2011). Marine pollution: let us not forget beach sand. Environ. Sci. Eur. 2011, 23, 40-43. doi: 10.1186/21904715-23-40

GESAMP (2015). "Sources, fate an effects of microplastics in the marine Environment: a global assessment," in Rep stud. GESAMP $N^{\circ} 90$, ed P. kershaw (IMO/FAO/UNESCOIOC/NIDO/IAEA/UN/UNDP Joint group of experts on trhe scientific aspects of Marine Environmental protection), 96.

Goldstein, M. C., Rosenberg, M., and Cheng, L. (2012). Increased oceanic microplastic debris enhances oviposition in an endemic pelagic insect. Biol. Lett. 8, 817-820. doi: 10.1098/rsbl.2012.0298

Gregory, M. R. (2009). Environmental implications of plastic debris in marine settings-entanglement, ingestion, smothering, hangers-on, hitch-hiking and alien invasions. Philos. Trans. R. Soc. Lond. B. Biol. Sci. 364, 2013-2025. doi: 10.1098/rstb.2008.0265

Harrison, J. P., Melanie, S., Michaela, S., and Mark, A. O. (2011). Interactions between microorganisms and marine microplastics: a call for research. Mar. Technol. Soc. J. 45, 12-20(9)

Jambeck, J. R., Geyer, R., Wilcox, C., Siegler, T. R., Perryman, M., Andrady, A., et al. (2015). Plastic waste inputs from land into the ocean. Science 347, 768-771. doi: $10.1126 /$ science. 1260352

Jorissen, F. (2014). "Colonization by the benthic foraminifer Rosalina (Tretomphalus) concinna of Mediterranean drifting plastics," in CIESM 2014. Marine litter in the Mediterranean and Black Seas. CIESM Workshop Monograph $n^{\circ} 46180$ p., ed F. Briand (Monaco: CIESM Publisher), 87-97.

Koelmans, A. A., Besseling, E.,Wegner, A., and Foekema, E. M. (2013). Plastic as a carrier of POPs to aquatic organisms: a model analysis. Environ. Sci. Technol. 47, 78127820. doi: 10.1021/es401169n

Law, K. L., Morét-Ferguson, S., Maximenko, N. A., Proskurowski, G., Peacock, E. E., and Hafner, J. (2010). Plastic accumulation in the North Atlantic subtropical gyre. Science 329, 1185-1188. doi: 10.1126/science.1192321

Macfayden, G., Huntington, T., and Cappell, R. (2009). Abandoned, Lost or Otherwise Discarded Fishing Gear. Rome: Food and Agriculture Organization of the United Nations publ.
Maso, M., Garces, E., Pages, F., and Camp, J. (2003). Drifting plastic debris as a potential vector for dispersing Harmful Algal Bloom (HAB) species. Sci. Mar. 67, 107-111. doi: 10.3989/scimar.2003.67n1107

Morét-Ferguson, S., Law, K. L., Proskurowski, G., Murphy, E. K., Peacock, E. E., and Reddy, C. M. (2010). The size, mass, and composition of plastic debris in the western North Atlantic Ocean. Mar. Pollut. Bull. 60, 1873-1878. doi: 10.1016/j.marpolbul.2010.07.020

Oehlmann, J., Schulte-Oehlmann, U., Kloas, W., Jagnytsch, O., Lutz, I., Kusk, K., et al. (2009). A critical analysis of the biological impacts of plasticizers onwildlife. Philos. Trans. R. Soc. B. 364, 2047-2062. doi: 10.1098/rstb.20 08.0242

Pham, C., Ramirez-Llodra, E., Alt, C. H. S., Amaro, T., Bergmann, M., Canals, M., et al. (2014). Marine Litter distribution and density in European Seas, from the Shelves to Deep Basins. PLoS ONE 9:e95839. doi: 10.1371/journal.pone.0095839

Pham, P. H., Jung, J., Lumsden, J. S., Dixon, B., and Bols, N. C. (2012). The potential of waste items in aquatic environments to act as fomites for viral haemorrhagic septicaemia virus. J. Fish Dis. 35, 73-77. doi: 10.1111/j.13652761.2011.01323.x

Rochman, C. M., Hoh, E., Kurobe, T., and Teh, S. J. (2013). Ingested plastic transfers hazardous chemicals to fish and induces hepatic stress. Nat. Sci. Rep. 3, 3263-3266. doi: 10.1038/srep03263

Teuten, E. L., Saquing, J. M., Knappe, D. R., Barlaz, M. A., Jonsson, S., Bjãrn, A., et al. (2009). Transport and release of chemicals from plastics to the environment and to wildlife. Philos. Trans. R. Soc. B 364, 2027-2045. doi: 10.1098/rstb.2008.0284

Van Cauwenberghe, L., Claessens, M., Vandegehuchte, M. B., and Janssen, C. R. (2015). Microplastics are taken up by mussels (Mytilus edulis) and lugworms (Arenicola marina) living in natural habitats. Environ. Pollut. 199, 10-17. doi: 10.1016/j.envpol.2015.01.008

Van Cauwenberghe, L., and Janssen, C. R. (2014). Microplastics in bivalves cultured for human consumption. Environ. Pollut. 193, 65-70. doi: 10.1016/j.envpol.2014.06.010

Van Cauwenberghe, L., Vanreusel, A., Maes, J., and Janssen, C. R. (2013). Microplastic pollution in deep Sea sediments. Environ Pollut. 182, 495-499. doi: 10.1016/j.envpol.2013.08.013

von Moos, N., Burkhardt-Holm, P., and Köhler, A. (2012). Uptake and Effects of Microplastics on Cells and Tissue of the Blue Mussel Mytilus edulis L. after an Experimental Exposure. Environ. Sci. Technol. 46, 11327-11335. doi: $10.1021 / \mathrm{es} 302332 \mathrm{w}$

Woodall, L. C., Robinson, L. F., Rogers, A. D., Narayanaswamy, B. E., and Paterson, G. L. J. (2015). Deep-sea litter: a comparison of seamounts, banks and a ridge in the Atlantic and Indian Oceans reveals both environmental and anthropogenic factors impact accumulation and composition. Front. Mar. Sci. 2:3. doi: $10.3389 /$ fmars. 2015.00003

Woodall, L. C., Sanchez-Vidal, A., Canals, M., Paterson, G. L., Coppock, R., Sleight, V., et al. (2014). The deep sea is a major sink for microplastic debris. R. Soc. Open Sci. 1:140317. doi: 10.1098/rsos.140317

Zettler, E. R., Mincer, T. J., and Amaral-Zettler, L. A. (2013). Life in the "plastisphere": microbial communities on plastic marine debris. Environ. Sci. Technol. 47, 713746. doi: 10.1021/es401288x

Conflict of Interest Statement: The author declares that the research was conducted in the absence of any commercial or financial relationships that could be construed as a potential conflict of interest.

Copyright (C) 2015 Galgani. This is an open-access article distributed under the terms of the Creative Commons Attribution License (CC BY). The use, distribution or reproduction in other forums is permitted, provided the original author (s) or licensor are credited and that the original publication in this journal is cited, in accordance with accepted academic practice. No use, distribution or reproduction is permitted which does not comply with these terms. 